\title{
Vloga konfucijanske ideologije pri oblikovanju nacionalne države na Japonskem
}

Ključne besede: konfucijanska ideologija, identiteta, nacionalna država, družinska država, konfucijanski nacionalizem

DOI: $10.4312 /$ ars.10.1.82-97

\section{Identitetni procesi na Japonskem}

Ideja o iskanju identitete ljudi kot procesu, ki pojasnjuje, kdo so ljudje in na kakšne načine se razlikujejo od svojih sosedov, je pri človeku vedno pristna. $\mathrm{V}$ okviru tega kompleksnega procesa so bili tudi na Japonskem izumljeni številni novi koncepti, kot na primer narod, etnos, kultura in identiteta; nastale pa so tudi številne razprave o etnogenezi. Raziskava o etnogenezi je bila na japonskih otokih pod velikim vplivom nacionalističnih diskurzov o japonski kulturi in je sprožila vrsto različnih predpostavk, ki so danes še vedno prisotne. Proces konstruiranja identitet, zlasti japonske nacionalne identitete, je bil še posebej intenziven v obdobju Meiji, tj. ko se je Japonska odprla svetu in je poskusila oblikovati nacionalno državo. Za to obdobje je torej značilna nova intenzivnost $\mathrm{v}$ razpravi o japonskih izvorih in različnih ideologijah, ki so se pojavile kot posledica novih raziskav v družboslovju.

V obdobju Meiji (1868-1912) so politiki sprejeli zamisel o nacionalni pripadnosti, ki je delovala kot temeljni kamen za oblikovanje moderne nacionalne države. Oblikovali so idejo o družinski državi (kazoku kokka 家族国家), ki vsebuje tradicionalno družinsko povezanost ali čut za družino (kazoku shugi 家族主義), podprt s konfucijansko etiko. Čut za družino, ki vključuje sistem širše družine, se je razširil na celoten narod, in sicer tako, da je vključeval cesarsko družino kot glavno družino vseh japonskih družin. To pomeni, da sta bili japonska tradicija čaščenja prednikov in podrejenost ostalih vej družin glavni družini integrirani za doseganje lojalnosti na nacionalni ravni.

Ker je večina identitet namišljen konstrukt, je tvorba "prave« identitete brezupna od samega začetka in pogosto vodi $\mathrm{v}$ podedovane fantazije o naravnih rasnih, etničnih in kulturnih dispozicijah. $\mathrm{Z}$ analizo besedil o japonski identiteti in nacionalizmu 
(glej Doak, 2007; Craig, 1968) lahko ugotovimo, da je nacionalizem v japonskem jeziku zelo občutljiv pojem, saj zanj obstaja več besed, kot sta kokuminshugi (国民 主義) in minzokushugi (民族主義); prav tako imajo Japonci dve različni besedi za »narod «: kokumin (国民) in minzoku (民族). ${ }^{1} \mathrm{~V}$ zadnjih nekaj letih je prišlo do naraščanja težnje po uporabi angleške besede za »nacionalizem« v fonetični obliki (nashonarizumu ナショナリズム) (Doak, 2007, 2). ${ }^{2}$ Vendar pa Nikole L. Freiner (2012) v svoji knjigi poudarja, da se je pod vplivom konfucijanske ideologije razvila še ena oblika nacionalizma. T. i. »konfucijanski nacionalizem« je eden od ključnih pojmov, ki definirajo japonsko nacionalno identiteto in je predstavljal »utrditev, ki je bila ključna pri strukturiranju odnosov med državljani in japonsko državo pri njeni ustanovitvi« (Freiner, 2012, 1). Poleg tega je vzdrževanje konfucijanskega nacionalizma na Japonskem vplivalo na socialne politike, politično vedenje in politične interakcije, ki so se pojavljale na Japonskem. Pojem konfucijanski nacionalizem ${ }^{3}$ nam pomaga razumeti specifične politike in odločitve politike, odnose Japonske s sosednjimi državami in cilje tuje diplomacijezunanje politike.

$\mathrm{V}$ prvem desetletju obdobja Meiji se je torej vlada osredotočila na centralizacijo in stabilizacijo svoje moči in oblasti, da bi si oblastniki zagotovili položaje in preprečili tuje intervencije (Tipton, 2002, 42). Medtem ko so domači dejavniki vedno igrali izredno pomembno vlogo pri oblikovanju politike, pa Japonska $\mathrm{v}$ tem obdobju ni več delovala kot zaprta država, izolirana pred tujimi vplivi, kot zadnjih 200 let. ${ }^{4}$ Leta 1868 je nova vlada v cesarjevem imenu razglasila splošna načela za prihodnost ter številne nove cilje, $\mathrm{v}$ katerih so se zrcalili nacionalistični motivi voditeljev vlade Meiji in spremenjen pogled na svet.

Ta članek bo tako poskušal odgovoriti, kako se je konfucijanstvo vključevalo v japonski okvir posodobitve nacionalne države v poznem 19. stoletju in kako je prišlo do opredelitve ene glavnih, če ne celo prevladujoče plasti zgodnjih modernih in sodobnih svetovnih nazorov.

1 Drug izraz, kokkashugi (国家主義), je v angleščino pogosto napačno preveden kot »nacionalizem《, vendar v resnici označuje to, kar v francoščini pomeni étatisme ali v angleščini statism. Podobno je treba koren besede kokka v angleščino prevesti kot »država« in ne »narod « (Doak, 2007, 2). Kokumin v slovenščini bolj odgovarja besedi »državljan«, minzoku pa besedi »narod «.

2 Ta pristop je imel v japonskem diskurzu o nacionalizmu dva učinka: pri prvem se je povečala teoretična dvoumnost glede tega, o čem točno se je razpravljalo (tj. »kaj je nacionalizem «); in drugič, težnja, da bi nacionalizem postal nekaj eksotičnega, kar prihaja z Zahoda oziroma je značilno samo zanj (Doak, 2007, 2).

3 Različice konfucijanskega nacionalizma je mogoče najti tudi v drugih azijskih državah, kot sta Južna Koreja in Tajvan (Freiner, 2012, 1).

4 Japonska je politiko »zaprte države« (sakoku) izvajala v celotnem obdobju Tokugawa (1600-1868). 


\section{Konfucijanstvo na Japonskem v obdobju Meiji}

Pomembnost konfucijanstva v japonski zgodovini je nesporna, saj je njegov vpliv segal v vse sfere sodobnega japonskega diskurza, vse od sodobne filozofije znanosti, religije ter humanističnih in družbenih ved. Konfucijanska besedila so na Japonsko prišla sredi 6. stoletja prek učenjakov korejske države Paekche. Ti so prišli na Japonsko poučevat kitajski jezik in politični sistem, prek katerega so prenašali tudi budizem. Izraza jugaku 儒学 in jukyō 儒教 se najpogosteje uporabljata, ko gre za sklicevanje na konfucijanstvo (tradicionalno in moderno) v japonski zgodovini (Tucker, 2013). Med 7. in 10. stoletjem je Japonska poskušala vzpostaviti centraliziran politični sistem s cesarjem na čelu in s skupino konfucijanskih birokratov (mandarinov); to je bil sistem, ki je temeljil na vzorcu kitajske dinastije Tang (618-907). S takšnim političnim sistemom, znanim kot sistem ritusuryō (律令), so poskušali zgraditi harmonično družbo s hierarhičnimi družbenimi odnosi in dolžnostmi. Vlada je poskušala uveljaviti celo konfucijanski sistem enakomerne porazdelitve zemljišč (handen-shūju 班田収受 制), veliko truda pa so vložili v uveljavitev konfucijanskih družinskih in sorodstvenih vrednot in praks. Ustanovljen je bil vladni kolegij za usposabljanje bodočih birokratov, kjer so kot osnovo izobraževanja uporabljali konfucijanske klasike. Vendar pa niso nikoli sprejeli kitajskega sistema preverjanja civilne službe, ki temelji na zaslugah. Doh Chull Shin $(2012,32)$ izpostavlja: »Ker so bili vladni uradni naslovi dodeljeni $\mathrm{z}$ rojstvom in ne $\mathrm{z}$ zaslugami, centraliziran birokratski sistem ni bil nikoli tako učinkovit, kot je bil v vladi Kitajske v obdobju Tang in Koreje v obdobju Yi.«

Tradicionalni sistem japonskih vrednot pred Obnovo Meiji zahteva podrobno razlago (glej Tucker, 2013; Bellah, 2003), vendar bi lahko na kratko rekli, da v kitajski in japonski družbi manjkajo transcendentalne vrednote, ki jih najdemo v zahodni tradiciji. Vrednote se $\mathrm{v}$ glavnem osredotočajo na ohranjanje in podporo skupine. Vendar pa obstaja tudi razlika med kitajsko in japonsko konfucijansko tradicijo znotraj istega tipa usmerjenih vrednot. Na Kitajskem očitno obstaja neke vrste univerzalna ideja, kot je Tian (nebesa), vendar pa ne zavzema transcendentalne vrednote. Ishida Yumiko to razlaga takole:

Ko so konfucijanske klasike predstavili na Japonskem, so se učenjaki pazljivo izogibali ideje spreminjanja mandata nebes, saj japonska cesarska vlada ni imela drugega vira legitimnosti kot prepričanje, da cesarska linija obstaja že od samega začetka zgodovine. V tem smislu je bil kitajski sistem tradicionalnih vrednot naravnan bolj univerzalno, japonski pa bolj partikularno, čeprav oba obstajata $\mathrm{v}$ okviru iste kategorije usmerjenih imanentnih vrednot (Ishida, 1996, 4). 
Shin $(2012,33)$ navaja, da so namesto konfucijanske doktrine kot glavnega načela vlade bolj uporabljali zakone in druge metode kot sredstvo za uvedbo pravne države. Poleg tega japonski sistem družbene etike ni poudarjal pomena družine in krvnih vezi pri vzpostavljanju mreže sorodstvenih razmerij, kot je bilo to na Kitajskem. Japonski etični sistem je bil naravnan bolj skupinsko kot kitajski sistem, saj so se odnosi pogosto razširili tudi izven krvnih vezi. Tako je japonski sistem od dveh konfucijanskih kreposti, zvestobe in ljubezni otrok do staršev, dal večji poudarek zvestobi vladarju in skupini kot pa ljubezni do staršev (Shin, 2012, 34).

V luči obnove države je leta 1868 prišlo tudi do nekaj sprememb na področju izobrazbe. Vse šole so bile reorganizirane po vzoru zahodnih vplivov, bistvo učnih načrtov pa ni bila več konfucijanska moralna vzgoja, ampak praktična znanja in spretnosti, ki so lahko koristne pri modernizaciji države. Vendar pa so voditelji konfucijanstvo uporabljali za uzakonitev svojih pravil in vzdrževanje reda. Japonce so silili, da so pasivno sprejeli njihovo avtoriteto (Shin, 2012, 34). Tako so kljub močni modernizaciji in zahodnim vplivom konfucijanski ideali še vedno ostali globoko zakoreninjeni v japonski politiki, saj je bila lojalnost cesarju določena $\mathrm{z}$ zakonom. Poraz Japonske v drugi svetovni vojni je bil hud udarec takšni vladi in tako se je konfucijanska ideologija vedno redkeje uporabljala za legitimiranje ukrepov oblasti, vendar je kljub temu tudi v naslednjih obdobjih vplivala na oblikovanje nacionalne države in japonske identitete.

\section{Oblikovanje nacionalne države in iskanje identitete}

Znotraj procesa oblikovanja nacionalne države so Japonci poskušali ugotoviti, od kod prihajajo in kdo so, ter opisati, kakšne so njihove značilnosti. Pri tem so uporabljali določene pojme, uvožene $\mathrm{z}$ Zahoda. Izraz »etničnost« so uporabili, ko so želeli definirati etnično identiteto, ki pa se nenehno vedno znova ustvarja s pomočjo interakcije v družbi. Kot pravi Simonu Kaner $(1996,56)$, etničnost »poudarja skupno preteklost, jezik, vero in materialno kulturo«. Etničnost je bila tako uporabljena v smislu kontinuitete (ne gre nujno za dejansko genetsko kontinuiteto), s pomenom kolektivnega spomina in usode. Kulturno razumevanje naroda je namreč utelešeno v nekaterih mitih, spominih, simbolih in vrednotah, ki jih ohranja določena kulturna skupina (glej več v Visočnik, 2004).

Kot navaja Mark Hudson (1999), so se raziskave japonske etnogeneze začele že veliko pred obdobjem Meiji. Hudson raziskave zgodovinsko razdeli na tri obdobja. Prvo sodi v čas okoli 16. stoletja s pojavom znanstvene arheologije. Zanj je bil značilen vzpon nacionalnega učenja (ali gibanja kokugaku 国学). Če želimo razumeti poglede 
na japonske korenine, moramo upoštevati poznavanje filozofske šole konfucijanstva in ne le gibanja kokugaku. Konfucijanski učenjaki so se osredotočali na besedila kitajskega zgodovinskega pisanja, medtem ko so nacionalistično usmerjeni učenjaki gibanja kokugaku poskušali očrniti kitajski vpliv na japonsko kulturo. Pred arheološkimi in antropološkimi pristopi je kot vir vedenja o izvoru Japoncev metoda analiziranja starih japonskih in kitajskih besedil predstavljala glavni vir informacij (Hudson, 1999, 24-25).

Drugo obdobje (1877-1935) je bilo zaznamovano z novo intenzivnostjo v razpravi o japonskem izvoru, ki se je pojavila kot posledica novih področij raziskovanja arheologije in antropologije. To je bilo obdobje prehoda med tekstovnim pristopom do preteklosti in ustreznim arheološkim pristopom, kar je bilo ključnega pomena za študij japonskih korenin. V začetku obdobja Meiji se je Japonska industrializirala in hkrati postala nacionalna država. Občutek nacionalne pripadnosti, ki se je pojavljal že v preteklem obdobju, ni bil več omejen samo na elito. V tem obdobju ga je politika sprejela kot temeljni kamen moderne nacionalne države (ibid., 34).

Značilnost tretjega obdobja je izrazit razvoj koncepta kulture v japonski arheologiji. Obrat od preteklosti in enostavnih etničnih interpretacij prejšnjega obdobja se je zgodil leta 1930. Simbol tega premika je mogoče videti v Razpravi Minerva ${ }^{5}$ leta 1936, ki je močno vplivala na večjo moč vojaških in nedemokratičnih sil na Japonskem. Vojna s Kitajsko je dosegla vrhunec leta 1937, japonska agresija pa se je nadaljevala do avgusta 1945, ko se je vojna v pacifiški regiji končala. V tem obdobju je bila Japonska strogo oblikovana in sistematično organizirana fašistična država, ki ji je vladala ultranacionalistična ideologija (ibid., 45-46).

Iskanje japonske identitete in razprava o njej se s tem obdobjem nista končala. Tako japonska identiteta še vedno nima dokončne definicije, kar je po Aminovem mnenju (1990) tudi nemogoče. Ta tema je še vedno v ospredju raziskav številnih učenjakov tako na Japonskem kot tudi po svetu (glej Visočnik, 2011).

Vendar pa je v obdobju Meiji Japonska spoznala, da mora postati močna neodvisna nacionalna država, če želi tekmovati s tujino, kar bi po mnenju politikov pripomogla vzpostavitev močne identitete. Glavna naloga, predvsem pod vplivom Zahoda, je bila, da kljub »heterogenosti« prebivalstva ustvari občutek »homogenosti« skupnosti. Ustvarjeni so bili ključni izrazi, kot so kazoku kokka (družinska država, Japonska kot velika družina s cesarjem na čelu kot očetom), minzuko (narod, ljudje, etnična pripadnost) in jinshu (rasa). Tako so politiki in učenjaki želeli poudariti spoznanje, da

5 Razprava Minerva je sklop debat, poimenovanih po časopisu Minerva, v katerem se je pojavila serija člankov in diskusij z okroglih miz. Pomemben fokus debat je bil konec obdobja Jōmon, učenjaki se namreč niso strinjali o tem, kako dolgo je ljudstvo Ainu še uporabljalo lončarstvo iz tega obdobja. 
je njihova nacionalna država zgolj sodobna manifestacija prvobitne skupnosti ${ }^{6}$ (vedno smo bili takšni, vedno smo isti), da so na Japonskem vedno živeli samo Japonci, ki so si delili japonsko kulturo in uporabljali japonski jezik. To pomeni, da je japonska država sinonim za japonski narod. Kar zadeva njihovo kulturo in gene, so izpostavili, da so popolnoma drugačni od držav, ki jih obkrožajo. Vse to kaže na vpliv zahodnih konceptov "znanstvenega « rasizma in socialnega darvinizma, kar pomeni, da so oni »sami« bolj civilizirani kot »drugi«, torej so pripadniki manjšin in tujci necivilizirani. ${ }^{7}$

Razprava o identiteti se je tako osredotočila na koncepta naroda in države, ki sta bistvenega pomena za študije politike in mednarodnih odnosov. Za večino držav bi bilo idealno, če bi v eni državi obstajal samo en narod; to bi bila idealna država. Toda narod je tudi čustveni koncept, ki temelji na ohlapnejši terminologiji: kultura, jezik, narodnost, vera in vse vezi, ki vežejo ljudi (Freiner, 2012, 1; glej tudi Doak, 2007). Na Japonskem je izraz narod mogoče najti v konceptu minzoku, torej ljudje iste etnične (nekateri trdijo »rasne«) skupine, in v kokumin, ki temelji na načelu ljudi, organiziranih v politično enoto (ki je lahko, vendar ne nujno, etnična). Beseda kokka se nanaša na »državo«. V tem okviru je jasno, da je beseda (in z njo koncept) minzoku nastala v nacionalističnem diskurzu obdobja Meiji (glej tudi Oguma, 2002). To je pripomoglo k bujenju in ohranjanju nacionalne zavesti. Vendar Yoon Keun-Cha (Doak, 2007, 15) trdi, da v prvi polovici obdobja Meiji (tj. do leta 1890) kolektivna ali skupinska zavest o enem etničnem narodu še ni bila jasno izražena in prisotna. To pomeni, da koncept »etnični narod « še ni bil v celoti oblikovan. Pravzaprav je bilo $\mathrm{v}$ času poustavne Japonske ${ }^{8}$ težko najti dejanske primere uporabe besede minzoku. Vsekakor v tistem času še ni bilo enotnega nacionalističnega gibanja, namesto tega so hkrati obstajali različni tokovi oblikovanja moderne nacionalne države in različne sile modernizacije. Politični voditelji in intelektualna elita so se osredotočili predvsem na usklajevanje niza vrednot, povezanih s konfucijanstvom, in konfucijanskega nacionalizma. Podobe in koncepte, kot so narod, dom in družina, so izkoristili, da bi poenotili japonsko nacionalno državo (Freiner, 2012, 14), hkrati pa je družbeni sistem poudarjal odgovornost znotraj medosebnih odnosov in družbene hierarhije.

Ideja, da dohitijo in presežejo zahodne sile, je v obdobju Meiji postala nacionalni cilj in je imela pomembno vlogo tudi v nacionalnem sistemu vrednot (Ishida, 1996, 5).

6 Izrazita primordialnost povzeta po Zahodu.

7 Več o tej ideologiji glej Visočnik, 2011.

8 Ustavo Meiji so razglasili leta 1889 in do leta 1890 so izdali še Cesarski edikt o izobraževanju (Kyōiku chokugo 教育勅語) (Akami, 2005, 128). Ta edikt je bil pomemben dokument, ki je v središče moralne izobrazbe kot vodnika nacionalne politike postavil konfucijansko misel. Bil je tudi sveti vodnik, ki so ga napisali japonski konfucijanci. Tako so utrjevali konfucijanske vrednote in indigene šintoistične mite o božanskem cesarskem poreklu, s čimer so izpostavili spoštovanje verskih načel, ki bi jih upoštevali vsi Japonci (De Vos, 1998, 114; glej tudi Tipton, 2002). 
Za doseganje cilja se je lahko uporabilo vse, kar je bilo mogoče, in to brez obotavljanja. Pomanjkanje transcendentalne vere na Japonskem se je izkazalo kot koristno in je razvoj modernizacije samo pospešilo. Ni bilo potrebe po sekularizaciji in tako se je Japonska pri sprejemanju zahodnih idej izkazala za bolj prilagodljivo kot Kitajska (ibid., 6).

\section{Ideologija družinske države in konfucianizem}

Po tako intenzivnem obdobju zgodnjega Meijija se je v drugi polovici obdobja zgodil obrat $\mathrm{h}$ konzervativizmu in nacionalizmu, le nekaj intelektualcev pa je zagovarjalo tudi zvesto vrnitev h konfucianizmu. Eden od teh filozofskih glasov je bil Inoue Tetsujirō, ${ }^{9}$ eden vodilnih, čeprav zelo nacionalističnih razlagalcev razvoja konfucianizma kot smeri v »filozofiji«, pri čemer je uporabil na novo skovano japonsko besedo za filozofijo, tetsugaku (哲学). Omeniti je treba tudi njegovo »nacionalno etiko« ali kokumin dōtoku (国民道徳); ta sklop učenja je v veliki meri temeljil na selektivnih konfucijskih vrlinah, kot so lojalnost, spoštovanje in ljubezen do staršev (ko 孝).

Inoue je poskušal razjasniti pojem »družinske države« ter je predstavil analogijo med družino in državo. Pri tem je uporabil dve temeljni konfucijanski moralni načeli. Ugotovil je, da je lojalnost ( chu 忠) do cesarja (tenno 天皇) identična spoštovanju in ljubezni do staršev ( $k o$ 孝), saj je bil cesar vodja države in družine. Pojasnil je tudi, »da bi moralo obstajati načelo poenotenja, saj je bila država organizem, sestavljen iz posameznih družin kot njenih celic« (Yoshino, 1995, 91).

Kljub idejam o tako strogem podrejanju cesarju in dojemanju cesarja kot očeta vsega ljudstva pa po mnenju De Vosa $(1998,114)$ Japonci niso občutili nobenega pritiska, ko so jim vladali po konfucijanskih načelih. Konfucijanstvo je podpiralo intelektualno moralno plat vedno obstoječega konflikta med družbeno obveznostjo ali giri (義理) ter bolj spontanimi, emocionalnimi družbenimi čustvi ali ninjo (人情). Giri je obredno povezan s predvidenim in pričakovanim, kar pomeni več formalnega upoštevanja moralnih pričakovanj $\mathrm{v}$ nasprotju s spontanostjo ljubezni in drugimi človeškimi čustvi. Občutki ninjo pa so bili bolj nevodeni in naravni. Konfucijanstvo je pri tem videti kot bolj formalno, »kitajskega« izvora.

Klasični konfucijanci menijo, da družina ni le naravna in biološka enota, saj predstavlja najbolj temeljno in prodorno enoto družbenega življenja. Shin $(2012,181)$ pri tem nadaljuje:

9 Inoue Tetsujirō 井上哲次郎 (1855-1944) je bil eden izmed najbolj eminentnih in vplivnih članov Tokijske cesarske univerze. Kot metafizik je bil zagovornik doktrine »fenomena resničnosti« (genshō sunawachi jitsuzai ron 現象即実在論). Bil je tudi plodovit zgodovinar japonske konfucijanske filozofije in teoretik »nacionalne etike» (Tucker, 2014, 36). 
Trije od petih kardinalnih človeških odnosov - oče in sin, mož in žena, starejši in mlajši brat - so prisotni v družini, in to služi kot okolje, v katerem se ljudje začnejo učiti, kako se vesti kot moralne osebe. Družina tako predstavlja temelj vseh drugih medosebnih odnosov kot najmočnejši in trajen vpliv na pravilen razvoj prihodnjih družbenih odnosov.

V konfucijanski tradiciji vrline, ki usmerjajo družinsko življenje, predstavljajo temelj vsem drugim vrlinam, vključno z zvestobo vladarju. To lahko vidimo na primeru, ko je Konfucij sinovsko pobožnost (xiao) poudaril kot najvišjo vrlino. Shin $(2012,180)$ je poudaril, da v konfucijanstvu družina predstavlja temelj vseh medosebnih odnosov, torej tudi tistih med ljudstvom in vladarjem. Konfucijanski vpliv se kaže tudi v tem, da ljudje bolj zaupajo tistim znotraj družinskega kroga kot ljudem od zunaj, kar je podpiralo družinsko naravnano državljansko in politično življenje. Zaradi tega je bila konfucijanska družinsko usmerjena etika »neskladna $z$ egalitarnimi načeli sodobnega civilnega in političnega življenja« (Shin, 2012, 180), kjer se ljudje ne poznajo med sabo.

Nikole L. Freiner $(2012,5)$ je trdila, da je japonski družbeni sistem okrepil odnose dvojne obveznosti znotraj hierarhije, kar je jasno razvidno $v$ hierarhiji nacionalne države. Prepričanje v kolektivizem pomeni, da je kolektivni interes Japoncev kot celote imel večjo vrednost kot korist posameznika. Pojem svobodnega in avtonomnega posameznika, kot ga je opredelila zahodna filozofija, v konfucijanski filozofiji ne obstaja. Namesto tega konfucijanska miselnost temelji na odnosu med ljudmi, katerih identitete se oblikujejo prek odnosov $\mathrm{z}$ drugimi, in med temi odnosi so družinski najpomembnejši.

Kohezivnost skupine še naprej ostaja enaka tudi po Obnovi Meiji, vendar se je spremenila velikost skupine. Ishida $(1996,4-5)$ je izjavil, da je v šogunatu Tokugawa han (fevd) predstavljal glavno središče lojalnosti. Kot rezultat zahodnega vpliva pa je postajal močnejši občutek nacionalnosti in žarišče lojalnosti se je v okviru nove vlade Meiji preusmerilo k nacionalni državi. Kot je bilo že prej omenjeno, se ta premik ni zgodil čez noč, a vendar je potencial za obstoj narodne zavesti obstajal že pred Meijijem. $\mathrm{V}$ obdobju tokugavskega režima je namreč že obstajala dobra komunikacijska in transportna mreža, kar je olajšalo pretok idej po vsej državi. Po drugi strani pa je trajalo nekaj časa, da je prišlo do vzpostavitve trdnejšega in politično učinkovitega občutka nacionalne identitete tudi po številnih spremembah v novem obdobju.

Ideje nekaterih konfucijancev lahko najdemo v Cesarskem ediktu o izobraževanju iz leta 1890, v katerem je navedeno, da je bil cesar božanstvo zaradi neprekinjene cesarske rodbine, ki sega daleč $\mathrm{v}$ preteklost (je potomec boginje Sonca). Cesar je tako predsedoval kot vodja glavne družine, iz katere naknadno izhajajo vse japonske družine (Yoshino, 1995, 65). Temelj takšnega cesarskega sistema je bil trdno zasidran 
v družinski povezanosti in ga je dopolnjeval državni šintoizem. ${ }^{10}$ Država je imela močan nadzor nad izobraževanjem v šolah. Po odprtju meja leta 1853 so izkušnje Japonske z ZDA privedle do hitre spremembe režima in integracije centralizirane oblasti. Pri tem se je vloga cesarja uradno in simbolično okrepila. Njena obnova je privedla do poenotenja Japonske in do prizadevanja za hiter gospodarski razvoj (Freiner, 2012, 5).

Tako je ideja o družinski državi, ki je nastala v tem obdobju, zgodovinsko vsebovala dva elementa. Prvi je že prej omenjen čut za družino, ki ga je podpirala konfucijanska etika. Razširili so ga na celoten narod, tako da je vseboval cesarsko družino kot glavno družino vseh japonskih družin. Drug element pa je organska teorija države, ${ }^{11}$ prinesena z Zahoda, še posebej iz Nemčije. Organska teorija države, ki je do določene mere ustrezala novoustanovljenemu birokratskemu sistemu, je bila pomembna pri izpodrivanju ideje ljudske suverenosti in naravnega prava, ki so jo zagovarjali aktivisti v gibanjih za »državljanske pravice« v poznih 70 . letih in $\mathrm{v}$ začetku 80. let 19. stoletja.

Takeshi Ishida (1996, xii) proces nastajanja ideje družinske države razlaga skupaj $\mathrm{z}$ njeno ideološko strukturo in dejanskim delovanjem $\mathrm{v}$ japonski družbi. Element spoštovanja in ljubezni do družine se je izkazal za koristnega pri mobilizaciji osebnega čustva, ki ga najdemo v družinskem razmerju, in pri prenosu tega čustva na lojalnost do države. Organska teorija države je bila pomembna za utemeljitev obstoječe zakonodaje in družbenega reda. Kawashima Takeyoshi (Yoshino, 1995, 65) je trdil, da je bila ideologija družinske države oblikovana s kombinacijo dveh tipov družinske povezanosti (kazokushugi), in sicer konfucijanske etike družinske povezanosti, omejene na družine samurajev v obdobju Tokugawa, in osnovne družinske institucije ie (家), razširjene med običajne ljudi. Tip družinske povezanosti med samuraji je bil usmerjen predvsem v »normativne zavesti«, medtem ko je bil tip, skupen navadnim ljudem, usmerjen $\mathrm{k}$ »čustvenim reakcijam «. Inoue tako status konfucijanskih pojmov povzdiguje ne nujno kot pojme same po sebi, ampak kot sestavne dele nacionalistične, imperialistične in militaristične mešanice, ki je služila interesom japonskih militaristov v 30. in 40. letih 20. stoletja. ${ }^{12}$

10 Jasna razlika mora biti med ljudskim šintoizmom, ki predstavlja indigeno animistično čaščenje prednikov med navadnimi ljudmi, in državnim šintoizmom, ki je moderna in spolitizirana nacionalistična ideologija, temelječa na čaščenju cesarja (Yoshino, 1995, 91).

11 Organsko teorijo države je pojasnil Baradat (Ishida, 1996), ki pravi, da je to »tip političnega kolektivizma, ki doseže, da država preseže posameznike znotraj države z močjo, zakoni in prioriteto. To idejo pogosto zasledimo pri Heglu, čeprav jo lahko povežemo tudi z antičnimi misleci, kot je Platon, in je imela velik vpliv v zelo raznolikih družbah, kot so sovjetska Rusija, nacistična Nemčija in komunistična Kitajska. Najdemo jo tudi v politični misli Woodrowa Wilsona in pri nekaterih drugih snovalcih ameriških političnih programov (npr. New Deal).

12 Po letu 1905 Inoue Tetsujirō iz filozofske zgodovine preide na delo, ki je preželo njegovo življenje v 
Podobno kot ideje Inoueja Tetsujiroja so tudi ideje Tanake Yoshita služile za razlago nekaterih osnovnih pojmov, začenši z nacionalizmom: »Za Japonce je država temelj njihovega življenja; temelji na hegemoniji države in prevladi nad člani družbe« (Isomae, 2014, 7). Tanaka je individualizem zavrnil kot »ideologijo, ki ustvarja konflikt med državo in posameznikom« (ibid.). Podobno je z njegovo idejo o družini (gospodinjstvu) (tj. 家), ki je podobna državi, kjer je družino razumel kot državo majhnega obsega, državo pa kot družino v velikem obsegu. Od ljudi so pričakovali, da so na cesarja gledali kot na glavo družine ter da so državi prisegli zvestobo, spoštovanje in ljubezen tako kot do staršev. Častili naj bi prednike, spoštovali rod družine in zagotovili kontinuiteto vseh obredov. Tanaka je imel podobno idejo kot Inoue tudi v tem, da je videl:

jedro edikta v ideji o posebni državi ter v etiki lojalnosti, spoštovanja in ljubezni do staršev, ki temeljita na nauku kokutai (国体 ali »nacionalni organ« ali »nacionalna politična identiteta «, "nacionalno bistvo«), ki združuje idejo države kot družine s teorijo države kot organskega telesa (Isomae, 2014, 242).

Novost Tanakovega pristopa pa je $\mathrm{v}$ tem, da je šintoizem postavil $\mathrm{v}$ središče nacionalno moralne doktrine, kot Isomae $(2014,242)$ navaja v svojem besedilu. To je pomembno tudi za konfucijanski nacionalizem. Nikole L. Freiner $(2012,4)$ predstavlja naslednje značilnosti konfucijanske ideologije znotraj konfucijanskega nacionalizma: 1) To je družbeni sistem, v katerem družina in dom služita kot model za učenje pravilnega vedenja, poudarek je na ohranjanju harmonije skozi vloge odnosov in odgovornosti, ki se vzajemno krepijo; 2) državne institucije in politiko uporablja za zavestno kodificiranje konfucijanskih načel; 3) verjame v zgodovinsko identifikacijo vladarja ali države z božanskim; vladar ima božanske lastnosti ali prednike in državne subjekte povezuje $z$ nebom, s čimer poudarja kulturno edinstvenost. Zaradi teh lastnosti so konfucijanski nacionalizem nekateri nacionalisti in imperialisti uporabili za krepitev ultranacionalizma, ki se je razvil pred drugo svetovno vojno in bil sredstvo za japonski imperializem.

Vsi ti procesi in ideologije imajo velik pomen za razvoj nacionalne identitete. Yoshino $(1995,160)$ navaja, da je bila japonska enorasna ideologija tesno povezana $\mathrm{z}$ ideologijo pred in med drugo svetovno vojno, $\mathrm{v}$ kateri je imela glavno vlogo Japonska kot družinski narod (ali družinska država) božanskega izvora. Člani

naslednjih štirih desetletjih. Opredelil je kokumin dōtoku, in sicer tako, da je bilo dovolj preprosto, da so ga lahko razumeli srednješolci, izobraženo prebivalstvo in člani cesarskih oboroženih sil. Čeprav Inoue nase nikoli ni gledal kot na zagovornika nacionalističnih, imperialističnih ali militarističnih ideoloških konstruktov, Tucker $(2014,36)$ meni, da je težko, da ne bi njegovih del videli v takšnem kontekstu, še posebej ko gre za povojno intelektualno zgodovinopisje. Njegov učenec Watsuji Tetsurō je bil še en intelektualec in filozof, ki je bil vpleten v nacionalistično propagando med drugo svetovno vojno (za več informacij glej Bellah, 1965). 
družinskega naroda naj bi bili krvno povezani med seboj in na koncu tudi s cesarjem, ki je predstavljal figuro matere (glej Bellah, 2003, 176). Koncept družinskega naroda predstavlja to, kar Armstrong imenuje »realizacija zamišljene skupnosti« (Yoshino, $1995,161)$. Sorodstvo, vera in rasa so se zlili med sabo, da bi nastal močan občutek kolektivne »enosti«.

\section{Zaključek}

V procesu oblikovanja identitete je šla Japonska skozi različne ravni razumevanja in interpretacije sebe in svojega okolja. Pod vplivom zahodnih teorij in konceptov je razvila svojo nacionalno identiteto in nacionalizem. Ti procesi so bili pod vplivom številnih ideologij, med njimi pa je pomembno vlogo odigrala tudi konfucijanska miselnost. Z Obnovo Meiji in vzpostavitvijo splošnega izobraževalnega sistema, ki je temeljil na konfucijanskih konceptih, predstavljenih znotraj nacionalističnega okvira, so se ti koncepti širili tudi med širše plasti prebivalstva. Meijijski Cesarski edikt o izobraževanju je imel $\mathrm{v}$ tem procesu pomembno vlogo kot dokument, s katerim je konfucijanska miselnost postala osrednjega pomena za moralno vzgojo in vodilo državne politike.

Konfucijanstvo je imelo velik vpliv na razvoj posebne oblike nacionalizma, tj. konfucijanskega nacionalizma, ki je strukturiral odnose med državljani in državo. Freiner $(2012,156)$ trdi, da prisotnost konfucijanskega nacionalizma na Japonskem opisuje pomembnost odnosov med ljudmi, še posebej družinskih razmerij. To je povezano z enim ključnih konceptov konfucijanstva, tj. čutom za družino, ki poudarja pomen močnih vezi med družinskimi člani ter opredeljuje posebne oblike mišljenja in vedenja. Ideologija družinske povezanosti je drugačna od ideologije individualizma, ki poudarja neodvisnost in samostojnost posameznika, saj podpira razširjenost družinske skupine ter njeno blaginjo postavlja pred interese in potrebe posameznih članov (Shin, 2012, 182).

Japonska vlada je uporabila to vrsto družinsko usmerjene ideologije in jo razširila na vso državo, tako da je družina postala temelj države, ter sinovsko pobožnost enačila z zvestobo cesarju. Cesar je bil oče vseh japonskih subjektov v družinski državi. Vse to je bilo mogoče, saj je Japonska kljub močnim zahodnim vplivom ohranila idejo cesarja $\mathrm{z}$ dolgo tradicijo, majhno število vrednot - lojalnost, spoštovanje in ljubezen do staršev ter harmonijo - in kup sloganov, ki so poudarjali bogastvo, moč in enotnost. Za modernizacijo države so te koncepte iz preteklosti preoblikovali v primerne oblike, ki so omogočile, da ima država trdno podporo v različnih segmentih tradicionalne družbe (Craig, 1973, 144). Glavna cilja države sta bila modernizacija in nacionalna hegemonija, za utrditev svoje simbolne moči so 
uporabili pripoved o »družinski državi«, kjer je družina predstavljala temelj države s pomočjo konfucijanstva in Cesarskega edikta o izobraževanju. Po besedah Iida Yumiko $(2002,18)$ je bil edikt »hvalnica japonskega naroda kot razširjene cesarske družine«.

Po mnenju nekaterih kritikov (Gluck, 1985, 280-281) je analogija med družino (kazoku)/gospodinjstvom) in japonsko državo (kokka) neutemeljena. Ta ideja je smiselna, ko gre za družine $\mathrm{z}$ dolgim rodom, kot so plemstvo, samuraji, stari posestniki, bogataši ter ljudje $\mathrm{z}$ vplivom in ugledom; ti so lahko čutili povezanost $\mathrm{s}$ cesarsko hišo, ki je lahko sledila svoji rodbini tudi »dva tisoč šeststo let « v preteklost. Vsekakor pa bi bilo preveč, če bi to zahtevali od ljudi, ki niso imeli ne priimkov ne nepremičnine in so bili sprejeti v »družinsko državo«. V teh primerih je šlo bolj za utopično idejo, ki pa je imela kljub vsemu velik vpliv na oblikovanje močnega nacionalizma, ki je vodil v imperialistično vojno. S porazom Japonske leta 1945 so konfucijansko miselnost začeli obravnavati negativno, in sicer zaradi njene nesrečne uporabe nekaterih filozofov in ideologov, kot je Inoue Tetsujirō. Manipulirali so s temeljno etiko konfucijanske filozofije, ki so jo preoblikovali v učenje lojalnosti do cesarske države ter požrtvovalnosti za cesarja in njegovo slavo. Na določeni točki so najbolj navdušeni konfucijanski filozofi trdili, da je bila Japonska pravo Centralno kraljestvo in ne Kitajska - in te filozofe so v povojnem obdobju namerno spregledali (Tucker, 2013).

Zgodba konfucijanstva $\mathrm{v}$ moderni Japonski je zelo zanimiva. Najprej so ga spregledali in nato - pred in takoj po obdobju Meiji - delno pomešali z oživljenim šintoizmom, v času, ko so zahodne ideje prihajale na Japonsko, pa so ga imeli za staromodnega. Kljub vsemu je pokazal neverjetno odpornost. Njegov preporod se je pospešil na začetku 20. stoletja, ko je postalo jasno, kako upada vrlina poslušne zvestobe in so se slabosti avtoritarne države širile s skupinami poslovnih moških, konservativnih politikov, birokratov in vojakov (Levi, 2013, 10). Konfucianizem je bil vključen v japonsko »nacionalno politiko« ter je tako postal sestavni del nacionalnega bistva in simbol nacionalnih tradicij, ki so jih slavili vsi nacionalisti.

Danes mnogi zgodovinarji pravijo, da obdobje Meiji predstavlja ključ do razumevanja sodobne japonske zgodovine, vendar pa so nekatere politike ali osebni pogledi razlagani preveč idealistično oziroma so napačno interpretirani. Predvsem ideja enega naroda v nacionalni državi je utopija, a je v nekaterih intelektualnih krogih in celo v politiki kljub temu še vedno prisotna. Kakršnakoli analiza takšnih ideologij zahteva previdnost in kritičnost. 


\section{Literatura}

Akami, T., Nation, State, Empire and War: Problems of Liberalism in Modern Japanese History and Beyond, Japanese Studies 25 (2), 2005, str. 119-140, http://dx.doi.org/ $10.1080 / 10371390500226043$ [16. 1. 2015].

Amino, Y., Nihonron no shiza. Rettō no shakai to kokka 二本論の視座. 列島の社会 と国家, Tokio 1990.

Bellah, R. N., Japan's Cultural Identity: Some Reflections on the Work of Watsuji Tetsuro, The Journal of Asian Studies 24 (4) (August), 1965, str. 573-594.

Bellah, R. N., Imagining Japan: The Japanese Tradition and Its Modern Interpretation, Berkeley, Los Angeles 2003.

Craig, A. M., Fukuzawa Yukichi: The Philosophical Foundation of Meiji Nationalism, v: Political Development in Modern Japan: Studies in the Modernization of Japan (ur. Ward, R. E.), New Jersey 1968, str. 99-148.

De Vos, G. A., A Japanese Legacy of Confucian Thought, v: Confucianism and the family (ur. Slote, W. H., De Vos, G. A.), New York 1998, str. 105-117.

Doak, K. M., A History of Nationalism in Modern Japan. Placing the People, Leiden, Boston 2007.

Freiner, N. L., The Social and Gender Politics of Confucian Nationalism: Women and the Japanese Nation-state, New York 2012.

Gluck, C., Japan's Modern Myths: Ideology in the Late Meiji Period, Princeton 1985.

Hudson, M., Ruins of Identity: Ethnogenesis in the Japanese Islands, Honolulu 1999.

Iida, Y., Rethinking Identity in Modern Japan. Nationalism as Aesthetics, London, New York 2002.

Ishida, T., Japanese Political Culture: Change and Continuity, New Jersey 1996 (1989).

Isomae, J., Religious Discourse in Modern Japan: Religion, State, and Shintō, Leiden 2014.

Kaner, S., Beyond Ethnicity and Emergence in Japanese Archaeology, v: Multicultural Japan: Paleolithic to Postmodern (ur. Denoon, D. in dr.), Cambridge 1996, str. 46-59.

Levi, N., The Impact of Confucianism in South Korea and Japan, Acta Asiatica Varsoviensia 26, 2013, str. 7-15.

Nakajima, T., The Restoration of Confucianism in China and Japan. A New Source of Morality and Religion, Essays on Japanese Philosophy, Nagoya, 2014, str. 37-50, https://nirc.nanzan-u.ac.jp/nfile/2100 [15. 1. 2015].

Oguma, E., A Genealogy of Japanese Self-images, translated by David Askew, Melbourne 2002. 
Shin, D. C., Confucianism and Democratization in East Asia, Cambridge, New York 2012.

Tipton, E., Modern Japan: A Social and Political History, London, New York 2002.

Tucker, J., Japanese Confucian Philosophy, v: The Stanford Encyclopedia of Philosophy (ur. Zalta, N. E.), 2013, http://plato.stanford.edu/archives/fall2013/entries/ japanese-confucian [20.9. 2014].

Tucker, J. A., Tokugawa Intellectual History and Prewar Ideology: The Case of Inoue Tetsujirō, Yamaga Sokō, and the Forty-Seven Rōnin, Sino-Japanese Studies, 14, 2014, str. 35-70, http://chinajapan.org/articles/14/14.35-70tucker.pdf [24. 1. 2015].

Visočnik, N., Identitetni procesi na Japonskem, Azijske in afriške študije 2/1, 2004, str. 45-58.

Visočnik, N., Hiša kot prostor identitete, Ljubljana 2011.

Yoshino, K., Cultural Nationalism in Contemporary Japan. A Sociological Enquiry, London, New York (1992) 1995. 


\section{Vloga konfucijanske ideologije pri oblikovanju nacionalne države na Japonskem}

Ključne besede: konfucijanska ideologija, identiteta, nacionalna država, družinska država, konfucijanski nacionalizem

Ideja o iskanju identitete kot procesu, ki pojasnjuje, kdo so ljudje, je pri človeku vedno prisotna. V okviru tega kompleksnega procesa so bili tudi na Japonskem izumljeni številni novi koncepti, poleg tega pa je bila raziskava o etnogenezi na japonskih otokih pod velikim vplivom nacionalističnih diskurzov o japonski kulturi in je sprožila vrsto različnih predpostavk, ki so danes še vedno prisotne. Proces konstruiranja identitet, zlasti japonske nacionalne identitete, je bil še posebej intenziven v obdobju Meiji (1868-1912), tj. ko se je Japonska odprla svetu in je poskusila oblikovati nacionalno državo. $\mathrm{V}$ tem obdobju so politiki sprejeli zamisel o nacionalni pripadnosti, ki je delovala kot temeljni kamen za oblikovanje moderne nacionalne države. Oblikovali so idejo o družinski državi (kazoku kokka 家族国家). Ta vsebuje tradicionalno družinsko povezanost ali čut za družino (kazoku shugi 家族 主義), ki je del klasične konfucijanske etike, vendar se nekoliko razlikuje od japonske interpretacije skupine. Čut za družino, ki vključuje sistem širše družine, se je razširil na celoten narod, in sicer tako, da je vključeval cesarsko družino kot glavno družino vseh japonskih družin. Ta članek bo tako poskušal odgovoriti, kako se je konfucijanstvo vključevalo $\mathrm{v}$ japonski okvir posodobitve nacionalne države v poznem 19. stoletju in kako je prišlo do opredelitve ene glavnih, če ne celo prevladujoče plasti zgodnjih modernih in sodobnih svetovnih nazorov. Pri tem bo skozi analizo konceptov kritično prevetril uporabo konceptov v teh procesih ter pogledal, kako so ti koncepti nastajali in se spreminjali glede na potrebe družbenega dogajanja. 


\section{Nataša Visočnik}

\section{The Role of Confucian Ideology in the Construction of the National State in Japan}

Keywords: Confucian ideology, identity, national state, family state, Confucian nationalism

The very ideas of searching for an identity of people living in Japan entails a process of having them explaining themselves and their country. Many new concepts were constructed within this process, and research into ethnogenesis on Japanese islands was under the great influence of nationalist discourses in Japanese culture, thus triggering a number of diverse assumptions which are still present today. The process of constructing identities, especially Japanese national identity, was intense during the Meiji period (1868-1912), i.e. when Japan opened up to the world and tried to form a national state under external influence. The politicians of this period adopted the sense of a national belongingness that was to function as the foundation stone for the modern national state. They formed the idea of a family state (kazoku kokka, 家族国 家) which contained traditional familism buttressed by Confucian ethics; however, it is still somehow different than the Japanese interpretation of the group. Familism, which included the extended family system, was expanded to cover the entire nation in a way that included the imperial family as the main family of all Japanese families. This paper thus tries to answer the question of how Confucianism was integrated within the Japanese context of the modernizing nation-states of the late nineteenth century and how it came to define one of the major or even the dominant layer of early-modern and modern worldviews. In doing so, the paper also critically questions the concept used in these processes and also looks into the way these concepts were constructed and were changing in accordance with social changes. 